\title{
TESTOSTERONE CHANGES IN PATIENTS WITH LIVER CIRRHOSIS BEFORE AND AFTER ORTHOTOPIC LIVER TRANSPLANTATION AND ITS CORRELATION WITH MELD
}

\author{
Rodrigo NITSCHE, Júlio Cezar Uili COELHO, \\ Alexandre Coutinho Teixeira de FREITAS, Clementino ZENI NETO and Eduardo MARTINS
}

\begin{abstract}
Context - Hypogonadism is a common clinical situation in male patients with liver cirrhosis. Objectives - The aim of the present study was to evaluate the effects of orthotopic liver transplantation on testosterone, free testosterone and sex hormone-binding globulin in male with advanced liver disease and also to determine the relationship of these changes with Model for End-stage Liver Disease (MELD) score. Methods - In a prospective study, serum levels of testosterone, free testosterone and sex hormone-binding globulin of 30 male adult patients with end-stage liver disease were measured 2 to 4 hours before and 6 months after orthotopic liver transplantation. Results - Total testosterone levels increased after orthotopic liver transplantation and the number of patients with normal testosterone levels increased from 18 to 24 . Free testosterone mean level in the pre-transplant group was $7.8 \mathrm{pg} / \mathrm{mL}$ and increased to $11.5 \mathrm{pg} / \mathrm{mL}(P=0.10)$ and sex hormone-binding globulin level decreased after orthotopic liver transplantation returning to normal levels in MELD $\leq 18$ - group (A) $(P<0.05)$. Conclusion - Serum level changes of testosterone, free testosterone and sex hormone-binding globulin are more pronounced in cirrhotic males with MELD $\leq 18$. Serum levels of testosterone and free testosterone increase and serum levels of sex hormone-binding globulin decrease after orthotopic liver transplantation.
\end{abstract}

HEADINGS - Liver transplantation. Testosterone. Liver cirrhosis.

\section{INTRODUCTION}

Hypogonadism is an important complication of end-stage liver disease. For many decades, the pathogenesis of the testicular atrophy and feminization that occur in men with chronic liver disease has fascinated both clinicians and biochemists ${ }^{(2)}$. Hypogonadism is more pronounced in patients with alcoholic cirrhosis because of the direct effect of ethanol on the testes. The pathogenesis of hypogonadism in patients with end-stage liver disease is complex and controversial.

Few studies have assessed the hypothalamic-pituitary-gonadal alterations in male cirrhotic patients before and after orthotopic liver transplantation (OLT). The correlation between testosterone changes and the Model for End-Stage Liver Disease (MELD) score has not been evaluated yet. The aim of the present study was to determine the effect of OLT on testosterone sex hormone levels in patients with end-stage liver diseases and also to determine the relationship of these changes with the MELD score.

\section{METHODS}

Of a total of 93 patients who underwent OLT at the Clinical Hospital of the Federal University of Paraná, Brazil, from August 2008 to January 2011, 30 males were prospectively selected to participate in the study. We excluded from the study patients $<18$ and $>65$ years of age and females, all the others patients submitted to OLT in this period were included. Patients subjected to living donor liver transplantation, re-transplantation, multiorgan transplantation, domino liver transplantation, split or reduced liver transplantation were excluded. Five patients died before the study completion and they were also excluded.

Ethical approval was obtained from the Hospital's Ethics Committee and informed consent was obtained from each patient prior to their inclusion in the study.

There were eight cases of alcoholic cirrhosis, 11 of viral cirrhosis, 3 cases of alcoholic and viral cirrhosis, 2 of hereditary hemochromatosis $(\mathrm{HH}), 3$ of nonalcoholic steatohepatitis (NASH), 1 of cryptogenic 
cirrhosis, 1 of hepatic venoocclusive disease and 1 of primary sclerosing cholangitis (Figure 1).

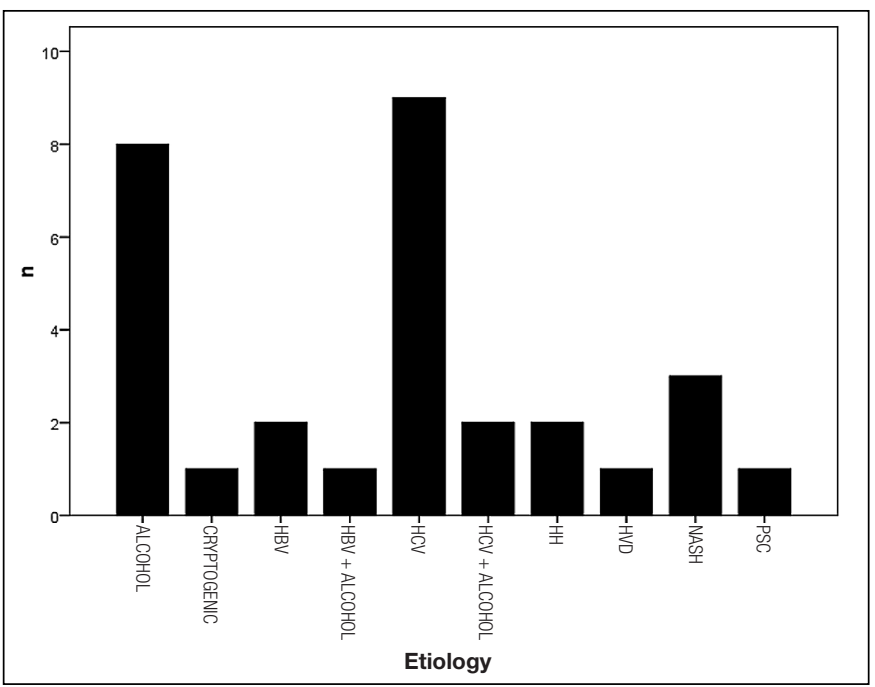

FIGURE 1. Etiology of the liver cirrhosis

Child-Pugh classification and MELD were used to determine the severity of liver disease. Four patients were ChildPugh class A (score 5 or 6 ), 10 were graded Child-Pugh class B (score 7-9) and 16 were graded Child-Pugh class C (score 10-15) (Table 1).

TABLE 1. Epidemiological and clinical characteristics of the patients

\begin{tabular}{lc}
\hline Characteristics & Patients \\
\hline Number & 30 \\
Age (year) & $51.4 \pm 7.6$ \\
$\quad$ Mean \pm SD & $25-64$ \\
$\quad$ Range & $30 / 0$ \\
Gender (male/female) & $\mathrm{N}(\%)$ \\
Etiology of cirrhosis & $9(30)$ \\
Chronic HCV infection & $8(26)$ \\
Ethanol chronic abuse & $2(7)$ \\
Chronic HBV infection & $3(10)$ \\
NASH & $2(7)$ \\
Hemochromatosis & $6(20)$ \\
Others & $6(20)$ \\
Hepatocarcinoma Associated & \\
Child-Pugh Score & $4(13)$ \\
A & $10(34)$ \\
B & $16(53)$ \\
C & \\
MELD score & $17(57)$ \\
$10-17$ & $11(37)$ \\
$18-22$ & $2(6)$ \\
$>23$ &
\end{tabular}

HCV: hepatitis C virus; HBV: hepatitis B virus; NASH: non-alcoholic steatohepatitis
MELD ranged from 10 to 30 points, with a mean of 17.7 \pm 4 .2. The mean value for MELD in patients that underwent transplantation was 17.7 and determined two groups to be analyzed: group A, with MELD $\leq 18$ and B, MELD $>18$. Additional points were not added to the MELD score of patients with associated hepatocellular carcinoma.

\section{Assays}

Peripheral venous blood samples were collected 2-4 hours prior to anesthesia induction for OLT and 6 months after the transplantation for determination of testosterone (ADVIA Centaur $^{\mathbb{B}}$ Testosterone Kit), free testosterone (calculated) and sex hormone-binding globulin (SHBG) (IMMULITE ${ }^{\circledR} 2000$ Kit) levels. Serum samples were kept frozen to be assayed later. Serum total bilirubin, pro-thrombin, and creatinine were measured by routine biochemical tests to determine the MELD on the day of OLT. After OLT all patients were placed on standard immunosuppressive protocol consisting of tacrolimus or cyclosporine, mycophenolate mofetil and corticosteroids.

\section{Statistical analysis}

All data were obtained and entered into a spreadsheet (Microsoft Excel ${ }^{\mathbb{R}}$ ) and later exported for further statistical analysis (Statistica - Statsoft $\left.{ }^{\circledR}\right)$. Values were expressed as means and standard deviation (mean $\pm \mathrm{SD}$ ) for continuous variables symmetrically distributed and as median, minimum and maximum values (median, minimum - maximum) for the asymmetric distribution. To estimate the difference of continuous variables with normal distribution parametric Student $t$ test was performed and for dependent samples and Anova for repeated measures and to estimate the difference of continuous variables with asymmetric distribution of variables the nonparametric tests Wilcoxon and Friedman Anova were used.

The MacNemar test was applied to study the behavior of hormonal and biochemical variables according to reference values, evaluating changes in categories: normal, below and above the reference value, before and after liver transplantation. Results were considered statistically significant when $P \leq 0.05$.

\section{RESULTS}

Our study population consisted of 30 male patients with mean age of $51.4 \pm 7.6$, ranging from 25 to 64 years. Four patients were Child-Pugh class A (score 5 or 6 ), 10 were class $\mathrm{B}$ (CPB; score 7-9), and 16 were class C (score 10-15). In 17 cases $(56.7 \%)$ MELD score was less than 18. MELD ranged from 10 to 30 points, with a mean of $17.7 \pm 4.2$ (Figure 2). Table 1 shows the epidemiological and clinical characteristics of the patients.

The results of sex steroids and sex hormone-binding globulin levels prior to and 6 months after liver transplantation are shown in table 2 . The patients were divided into two groups according to average of MELD score before OLT: A $(\leq 18)$ and B $(>18)$. In the group A, it was observed an 


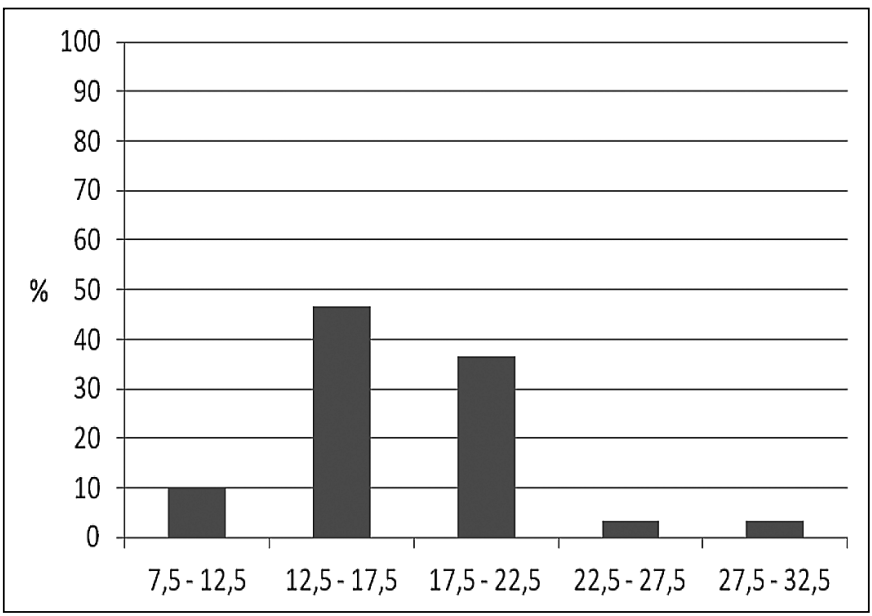

FIGURE 2. Interval distribution of MELD score

TABLE 2. Laboratory tests before and after OLTx

\begin{tabular}{lccc}
\hline Lab test & Pre-OLT & Pos-OLT & $P$ value \\
\hline $\begin{array}{l}\text { Total testosterone } \\
(\mathrm{ng} / \mathrm{dL})\end{array}$ & $418.0(15-1299)$ & $395.5(56-927)$ & $0.73 * *$ \\
$\begin{array}{l}\text { Free testosterone } \\
(\mathrm{pg} / \mathrm{mL})\end{array}$ & $7.8(0.2-43)$ & $11.5(4.9-260)$ & $0.10 * *$ \\
SHBG $(\mathrm{nmol} / \mathrm{L})$ & $55.5(9-162)$ & $35.5(5.8-83)$ & $0.007 * *$ \\
\hline
\end{tabular}

** Wilcoxon test; OLT: orthotopic liver transplantation; SHBG: sex hormone-binding globulin.

increase in serum levels of free testosterone $(P<0.03)$ and a decrease in SHBG levels $(P=0.008)$ after OLT. The patients of B group also had an increase in free testosterone (FT) $(P=0.95)$ and decrease in SHBG $(P=0.57)$ levels (Figures 3 and 4 ) after OLT. Total testosterone serum levels had no

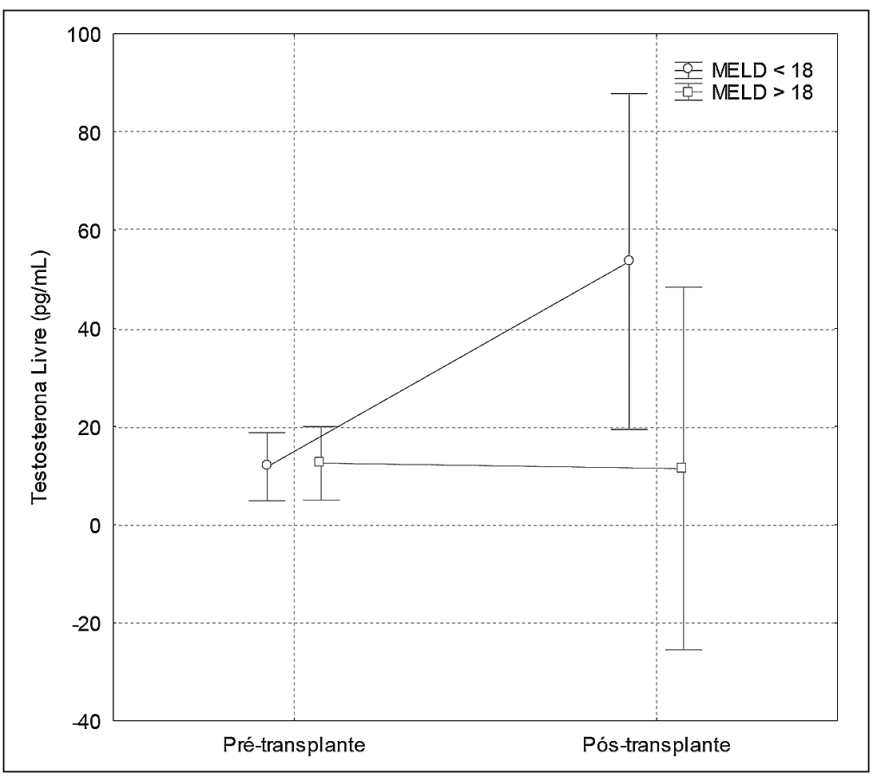

FIGURE 3. Free testosterone variation according to MELD score in groups $\mathrm{A}$ and $\mathrm{B}$

Note: Friedman Anova

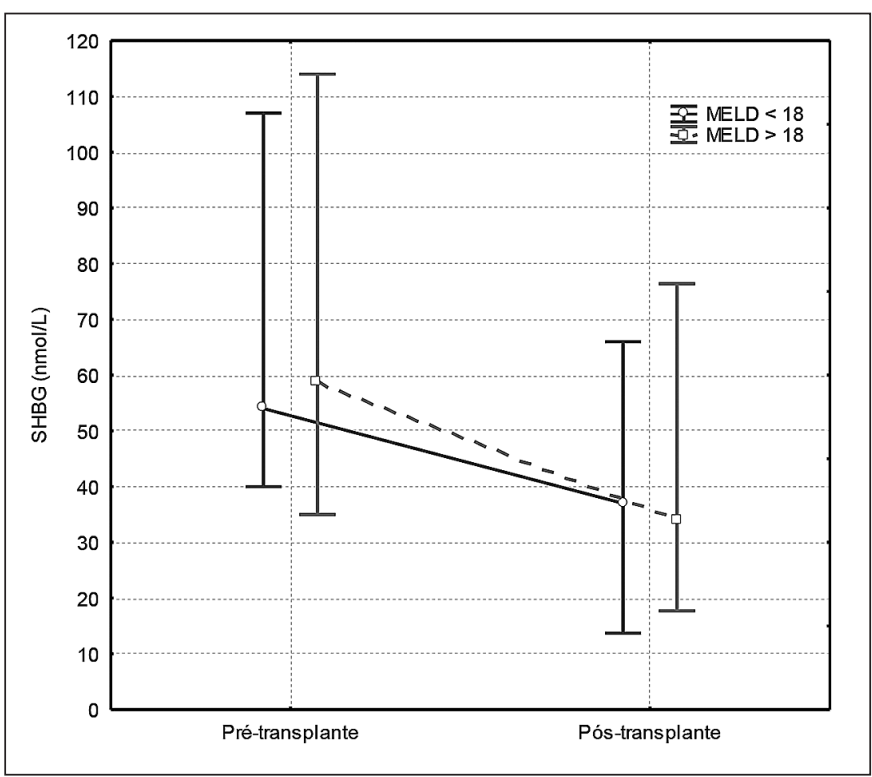

FIGURE 4. Sex hormone-binding globulin (SHBG) variation according to MELD score in groups A and B

Note: Friedman Anova

significant changes after OLT. A total of $18(66.7 \%)$ patients had normal testosterone levels before OLT and $24(88,9 \%)$ after OLT. Seven of 8 patients with low serum levels of total testosterone increased to normal level after OLT $(P<0.001$, McNemar test) (table 3). We also divided the patients according to the etiology into alcoholic (group $\mathrm{C}=8$ patients) and non alcoholic (group D $=22$ patients), and analyzed the different results according to each hormone. FT levels increased more in group D $(P=0.004)$ than in group $\mathrm{C}$ $(P=0.36)$ and SHBG decreased more in $\mathrm{C}(P=0.03)$ than in $\mathrm{D}(P=0.22)$. Total testosterone level variation was simi-

TABLE 3. Total testosterone before and after olt according to McNemar test

\begin{tabular}{lcccc}
\hline Before OLTx & \multicolumn{4}{c}{ After OLTx } \\
$\begin{array}{l}\text { Reference } \\
\text { value }\end{array}$ & Normal & Below & Above & Total \\
\hline Normal & 16 & 01 & 01 & 18 \\
& $(59.3 \%)$ & $(3.7 \%)$ & $(3.7 \%)$ & $(66.7 \%)$ \\
& & & & \\
Below & 07 & 01 & 00 & 08 \\
& $(25.9 \%)$ & $(3.7 \%)$ & $(0.0 \%)$ & $(29.6 \%)$ \\
& & & & \\
Above & 01 & 00 & 00 & 01 \\
& $(3.7 \%)$ & $(0.0 \%)$ & $(0.0 \%)$ & $(3.7 \%)$ \\
& & & & \\
Total & 24 & 02 & 01 & 27 \\
& $(88.9 \%)$ & $(7.4 \%)$ & $(3.7 \%)$ & $(100.0 \%)$
\end{tabular}

Note: McNemar test; OLT: orthotopic liver transplantation 
lar in both groups $(P>0.05)$. These differences are shown in figures 5 and 6 .

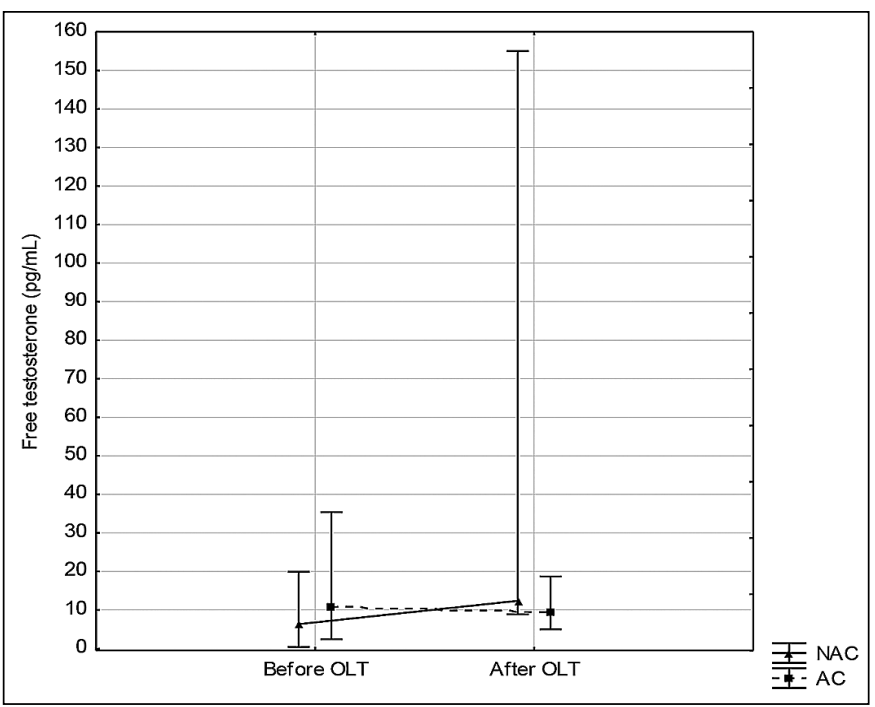

FIGURE 5. Free testosterone levels according to etiology: $\mathrm{C}(\mathrm{AC})$ and $\mathrm{D}$ (NAC) groups

Note: Friedman Anova

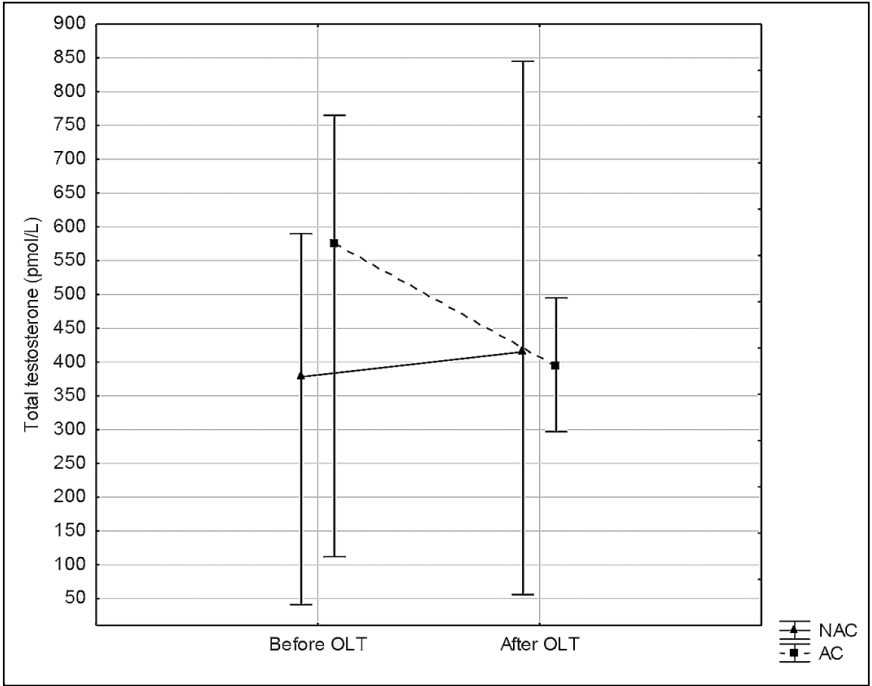

FIGURE 6. Total testosterone levels according to etiology: C (AC) and $\mathrm{D}$ (NAC) groups

Note: Friedman Anova

\section{DISCUSSION}

The pathogenesis of hypogonadism in cirrhotic patients is complex and not well elucidated. It involves both a gonadal and a hypothalamic-pituitary dysfunction ${ }^{(7,18)}$ which is shown in laboratory tests by a decrease in gonadotropins (FSH and $\mathrm{LH}$ ), total testosterone and FT serum levels. Karagiannis et al. ${ }^{(11)}$ showed that after OLT the hypothalamic-pituitarygonadal function improves partially, showing that the hepatic dysfunction before OLT is important in its pathogenesis.
Southren et al. ${ }^{(16)}$ demonstrated a decreased plasma level and production rate of testosterone in cirrhosis of the liver and that the mechanism of the hypogonadism is probably secondary to hypothalamic-pituitary suppression rather than to primary testicular dysfunction.

Clinical signs of relative androgen deficiency in men are a decrease in muscle mass and strength, osteoporosis and an increase in central body fat. These findings are not specific to the low androgen state but they may suggest testosterone deficiency. In male cirrhotic patients, hypogonadism manifests with loss of libido, testicular atrophy, ejaculatory dysfunction and signs of feminization (hyperestrogenism and gynecomastia). The biochemical bases of these phenomena were shown in the present study and in others. Testosterone serum level is lower than in normal patients ${ }^{(5,7,9)}$ which masks a marked fall in the non-protein-bound (biologically active) fraction of the hormone due to a large increase in the sex hormone-binding globulin $(\mathrm{SHBG})^{(3,7,10)}$ which binds testosterone with a high affinity. Most circulating testosterone is bound SHBG and only the small proportion in the free form is biologically active $^{(8,13)}$. Our prospective study has shown that serum levels of FT increased in A group $($ MELD $<18)$ after OLT $(P<0.05)^{(13)}$ and we did not find significantly changes in total testosterone serum levels after transplantation $(P=0.73)$.

Madersbacher et al. ${ }^{(12,13)}$ reported that the normalization of liver function following OLT is characterized by an early rise in free testosterone, consistent with our findings. In the sixties Rosenbaum et al..$^{(15,17)}$ were the first to call attention to increased levels of an steroid-binding protein in the plasma of men with cirrhosis. Nguyen et al. ${ }^{(14)}$ added that severe liver disease was associated with lower free testosterone and higher sex hormone-binding globulin levels.

Our data confirm previous findings that SHBG concentration is increased in patients with cirrhosis ${ }^{(1,10)}$ and returns to normal levels after OLT. In addition, the increase in SHBG leads to a stronger binding with testosterone ${ }^{(8,13)}$. In cirrhotic patients occur an increase in the peripheral conversion of androgens into estrogens $s^{(4,6,7)}$ and a decrease in the liver depuration of estrogens. Southern et al. ${ }^{(16)}$ also reported that accelerated conversion of testosterone to androstenedione may explain, in part, the presence of increased circulating estrogens in cirrhosis, since it has been reported that androstenedione is a more efficient precursor than testosterone for estrogen synthesis.

Finally, the present study demonstrates that MELD score was useful not only to classify the severity of liver dysfunction but also to determine a group with more significant hormonal changes after OLT. In other words, the lower the MELD score before OLT, the greater the changes in hormone levels 6 months after.

\section{CONCLUSION}

It is concluded from the present study that changes in serum levels of testosterone, FT, and SHBG are more pronounced in cirrhotic males with MELD $\leq 18$. Serum levels of testosterone and free testosterone increase and serum levels of SHBG decrease after OLT. 
Nitsche R, Coelho JCU, Freitas ACT, Zeni Neto C, Martins E. Alterações nos níveis de testosterona em pacientes com cirrose hepática após transplante hepático ortotópico e sua correlação com o MELD. Arq Gastroenterol. 2014,51(1):59-63.

RESUMO - Contexto - O hipogonadismo é uma situação clínica comum em pacientes do sexo masculino com cirrose hepática. Objetivos - O objetivo do presente estudo foi avaliar os efeitos do transplante hepático ortotópico nos níveis de testosterona, testosterona livre e globulina de ligação do hormônio sexual na doença hepática avançada em homens e, determinar a relação dessas mudanças com o Model for End-stage Liver Disease (MELD). Métodos - Em um estudo prospectivo, os níveis séricos de testosterona, testosterona livre e globulina de ligação do hormônio sexual de 30 pacientes adultos do sexo masculino com doença hepática em estágio final foram medidos 2 a 4 horas antes e 6 meses após transplante hepático ortotópico. Resultados - Os níveis de testosterona total aumentaram após transplante hepático ortotópico e o número de pacientes com níveis normais de testosterona aumentou de 18 para 24. O nível médio de testosterona livre no grupo de pré-transplante foi de 7,8 pg/mL, aumentou para 11,5 pg/ $\mathrm{mL}(P=0,10)$ e globulina de ligação do hormônio sexual diminuiu após transplante hepático ortotópico retornando aos níveis normais no grupo com MELD $\leq 18$ - grupo (A) $(P<0,05)$. Conclusão - As mudanças nos níveis séricos de testosterona, testosterona livre e globulina de ligação do hormônio sexual são mais pronunciadas em homens com cirrose e MELD $\leq 18$. Os níveis séricos de testosterona e testosterona livre aumentaram e de globulina de ligação do hormônio sexual reduziram após transplante hepático ortotópico. Os níveis de testosterona livre aumentaram em pacientes com cirrose hepática avançada após transplante hepático ortotópico enquanto globulina de ligação do hormônio sexual diminuiu após transplante hepático ortotópico e estas alterações foram mais intensas em pacientes com MELD $\leq 18$.

DESCRITORES - Transplante de fígado. Testosterona. Cirrose hepática.

\section{REFERENCES}

1. Floreani A, Mega A, Tizian L, Burra P, Boccagni P, Baldo V, Fagiuoli S, Naccarato R, Luisetto G. Bone Metabolism and Gonad Function in Male Patients Undergoing Liver Transplantation: A Two-Year Longitudinal study. Osteoporos Int. 2001;12:749-54.

2. Galvão-Teles A, Burke CW, Anderson DC, Marshall JC, Corker CS, Bown RL, Clark ML. Biologically active androgens and oestradiol in men with chronic liver disease. Lancet. 1973;1:173-6.

3. Gluud C, Bennett P. Comparison of methods for determination of testosterone and non-protein bound testosterone in men with alcoholic liver disease. Scand $\mathbf{J}$ Clin Lab Invest. 1986;46:647-53.

4. Gluud C. Serum testosterone concentration in men with alcoholic cirrhosis background for variations. Metabolism. 1987;36:373-8.

5. Gluud C. Testosterone and alcoholic cirrhosis. Epidemiologic pathophysiologic and therapeutic studies in men. Dan Med Bull. 1988;35:564-75.

6. Gordon GG, Olivo J, Rafil F, Southren AL. Conversion of androgens to estrogens in cirrhosis of the liver. J Clin Endocrinol Metab. 1975;40:1018-26.

7. Guéchot J, Chazouillères O, Loria A, Hannoun L, Balladur P, Parc R, Giboudeau $\mathrm{J}$, Poupon R. Effect of liver transplantation on sex-hormone disorders in male patients with alcohol-induced or post-viral hepatitis advanced liver disease. Journal of Hepatology. 1994;20:426-30.

8. Handelsman DJ, Strasser S, McDonald JA, Conway AJ, McCaughan GW. Hypothalamic-pituitary-testicular function in end-stage non-alcoholic liver disease before and after liver transplantation. Clin Endocrinol. 1995;43:331-7.

9. Johnson PJ. Sex hormones and the liver. Clin Sci. 1984;66:369-76.
10. Kalyani RR, Gavini S, Dobs AS. Hypogonadism in systemic disease. Endocrinol Metab Clin North Am. 2007;36:333-48.

11. Karagiannis A, Harsoulis F. Gonadal dysfunction in systemic diseases. Eur $\mathbf{J}$ Endocrinol. 2005;152:501-13.

12. Madersbacher S, Grünberger T, Maier U. Andrological status before and after liver transplantation. J Urol, 151:1251-4, 1994.

13. Madersbacher S, Ludvik G, Stulnig T, Grünberger T, Maier U. The impact of liver transplantation on endocrine status in men. Clin Endocrinol. 1996;44:461-6.

14. Nguyen HV, Mollison LC, Taylor TW, Chubb SA, Yeap BB. Chronic hepatitis $\mathrm{C}$ infection and sex hormone levels: effect of disease severity and recombinant interferon-alpha therapy. Intern Med J. 2006;36:362-6.

15. Rosenbaum W, Christy NP, Kelly WG. Electrophoretic evidence for the presence of an estrogen-binding beta-globulin in human plasma. J Clin Endocr Metab. 1966;26:1399-403.

16. Southren AL, Gordon GG, Olivo J, Rafii F, Rosenthal WS. Androgen metabolism in cirrhosis of liver. Metabolism. 1973;22:695-701.

17. Tavernetti RR, Rosenbaum W, Kelly WG, Christy NP, Roginsky MS. Evidence for the presence in human plasma of an estrogen-binding factor other than albumin: abnormal binding of estradiol in men with hepatic cirrhosis. J Clin Endocrinol Metab. 1967;27:920-6

18. Van Thiel DH, Kumar S, Gavaler JS, Tarter RE. Effect of liver transplantation on the hypothalamic-pituitary-gonadal axis of chronic alcoholic men with advanced liver disease. Alcohol Clin Exp Res. 1990;14:478-81.

Received 29/7/2013 Accepted 8/11/2013 